\title{
International trade promotion methods for SMEs in low and lowe r-middle-income economies
}

\section{John Solunta Smith}

Lecturer, Development Policy Studies, University of Liberia

\begin{abstract}
Purpose: The study examines the determinants of SMEs international trade promotion in low and lower-middle-income economies. It also aims to further explain the participation or nonparticipation of SMEs in international trade promotion; recommended policies to increase SMEs' international trade promotion.
\end{abstract}

Research methodology: The author used the Gravity Theory in economics with mixed methods on the World Bank enterprises Survey dataset 2009 - 2018, using panel data regression models.

Tests of multicollinearity using Stata entirely guided the models. The Pairwise correlation, the variance inflation factors, hausman test, testparm, and reverse causality test using the Poisson Pseudo Maximum Likelihood Model estimator were used.

Findings: The results show that Small enterprises do not significantly promote international trade, while medium enterprises

Article History

Received on 24 December 2019

$1^{\text {st }}$ Revision on 25 December 2019

$2^{\text {nd }}$ Revision on 31 December 2019

$3^{\text {rd }}$ Revision on 15 January 2020

$4^{\text {th }}$ Revision on 4 February 2020

$5^{\text {th }}$ Revision on 10 February 2020

Accepted on 12 February 2020 significantly do. The study finds rule of law, education, bank private credits, firms' age, and trade openness as major determinants of SME trade promotion while inflation and tax constraints are somewhat determinants. The study found no evidence of reverse causality between exports and SMEs.

Limitation: The study is limited in the coverage of the Key Informants Interviews (KII) used by the author to inform the discussion. The KII was only conducted in Liberia with SMEs engaged in exporting while the research data covered 56 low and lower-middle-income economies. Future expansion in the coverage of the KII is recommended.

Implication: This study will be useful for policymakers who are engaged with the development of SMEs in low and lower-middleincome countries and academics in the fields of economics and international business management

Keywords: Gravity model, SMEs, Trade promotion

How to cite: Smith, John Solunta. (2020). International trade promotion methods for SMEs in low and lower-middle-income economies. International Journal of Financial Accounting and Management, 1(3), 131-145.

\section{Introduction}

SMEs have been regarded as the drivers of growth in the domestic economies in developing countries. They are accredited for creating jobs and positively moving domestic trade in expanding the value chain in the production processes $(\mathrm{OECD}, 2000)$. On the other hand, author such as Corte, (2014) attempted to measure their international contributions to foreign trade attraction and helping developing 
countries generate export earnings that could help ignite development. Similarly so, consistent with the literature, authors Leegwater and Shaw, (2008) at the IRIS Center used a regression approach to study SMEs' contribution to Economic Growth in selected developing countries .Despite data challenges as reported by these scholars, they found evidence that SMEs are supporting economic growth in the local economies using a cross-sectional model.

Firm-level literature and trading experiences from both developing and developed countries surveyed have shown that micro and small enterprises are participating in international and cross border trade through several pathways that go beyond importation of goods and services and backward integration (Paul, J., Parthasarathy, S., \& Gupta, P., 2017). The few researchers who have committed their attention to SMEs internationalization have not been able to quantify and show the level of participation or non-participation; instead, they have concentrated of the ability of SMEs to export and overcome export barriers (Leegwater \& Shaw, 2008; Calof, J. L. 1994). Other authors have been carried away by the miniature capital base of SMEs, forgetting that technology and globalization are aiding SMEs' international market penetration nowadays. The study fills this gap by looking deeper into account of SME trade participation and promotion of International Trade in Low and lower-middleincome Economies in the World. This study is in support of the call made earlier on by Calof, (1994), which recommended that SMEs engage in International Trade promotion.

\subsection{Problem statement}

Low and lower-middle-income countries remain challenged with low value-added and manufacturing exports. Beyond the natural resources they export to the Americas and Europe as major trading partners, they do not mostly trade with each other. There have been poor records of intra-trade with these economies. For example, in Africa, neighbouring countries rarely trade with each other. Although other study such as Khana Group (2018) finds that Cross border trade in the region is often made informal. There is no formal sustainable trade among these neighbouring countries. Trade economists on the continent believed that this is so probably because of the trade structure and the similarity in natural endowments they share. Take, for instance, Liberia is rich with iron ore, diamond, gold, among others but it cannot trade with Guinea or Sierra Leone with the same trade structure and endowments. As a result of these economies' trade structures, their exports in the natural resources cannot help their economies gain stabilization amid global commodities price fluctuations. This has consistently contributed to the increase unemployment and price instability deriving from the search for foreign currency for the importation of goods by businesses.

A look at the imports versus exports records in the region showed that there are imbalances in the region trade skewed towards imports only without corresponding exports.

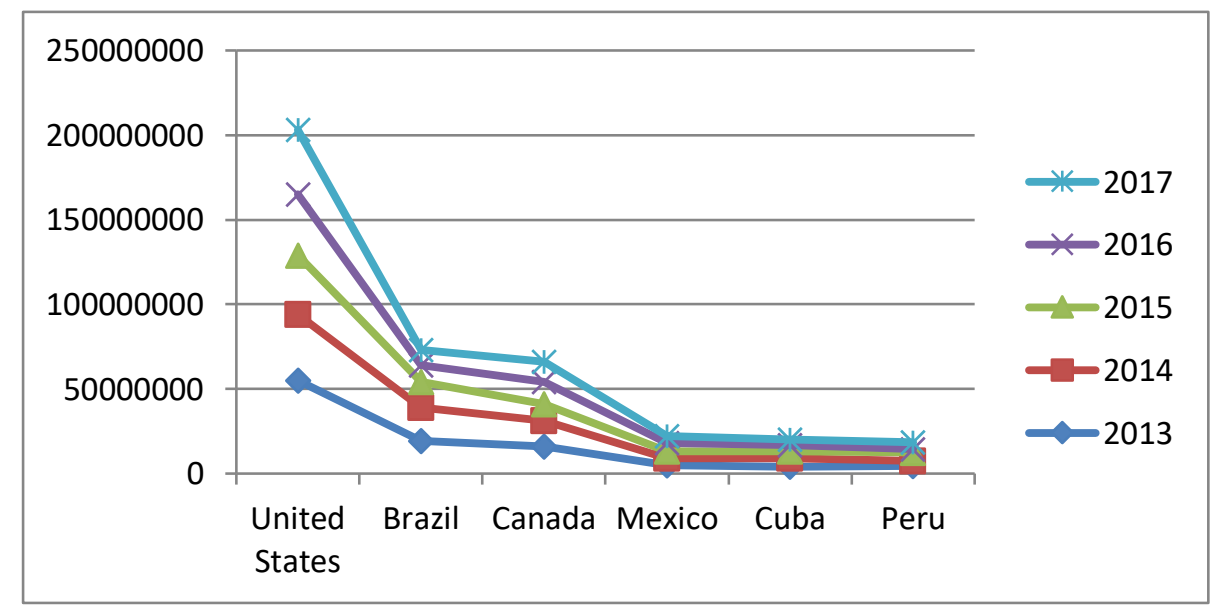

Figure 1.1: Africa's exports destinations from $2013-2017$

Source: World Trade Organization, Directory of Trade Statistics (DOT). 


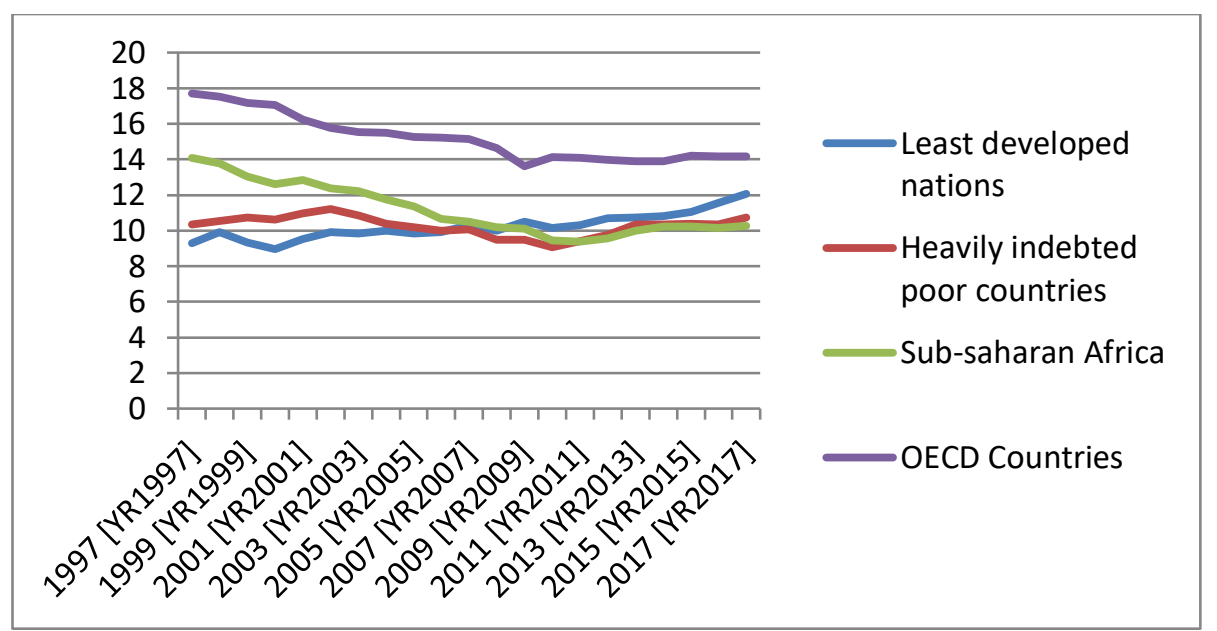

Figure 1.2: Composition of value-added manufacturing trading exporting Source: World Development Indicator dataset

Figure 1.2 above shows that the trade of low and lower middle-income countries has not brought the expected return due to the lack of value addition that excludes SMEs active participation. Exports from manufacturing services and enlarging the value chain for Agricultural products help create jobs and make national development flourish. Without exports, foreign capital will be scarcity and limited technology and managerial skills that are usually generated through FDI. The lack of technology or scientific, managerial skills in the production process leads SMEs not to enjoy economies of scale.

\subsection{The purpose of the study}

The purpose of this study is summarized in the specific objectives as follow:

1. Explain the participation or non- participation of SMEs in international trade promotion;

2. Examine the determinant of SMEs trade promotion in low and lower-middle income economies

3. Recommend policies that will help to increase SMEs' international trade promotion?

\subsection{Research questions}

With these objectives in mind, the author raised three research questions.

1. Does the enterprise size matter in trade promotion?

2. What are the determinants of SMEs' international trade promotion in low and lowermiddle-income economies?

3. What policies could help to increase SMEs trade participation level in foreign trade promotion low and lower-middle-income economies?

\section{Literature review and hypotheses development}

The author surveyed the related literature on the exporting behaviour of SMEs and defined the concept of their internationalization. The author also discussed some national definitions of SMEs and concluded with the standard definition adopted from the World Bank enterprise Survey as the working definition for the uniqueness and standardization of this paper. The author used a standard Gravity Theory of International Trade as the fundamental theory to test the variables in this research paper.

\subsection{Definitions of internationalization of SMEs / classifications}

For this study, the authors considered two separate definitions of SMEs internationalization. According to Corte, (2014), 'internationalization is an orderly, continue and incremental trade from domestic operations to the international market through exports' (p.1-34). Secondly, we adopt further definition from Wight et al., (1991) and Calof, (1994) that the term internationalization is heavily concentrated in terms of SMEs exports and their ability to purchase and survive in the foreign markets Corte, (2014). These definitions set the stage for examining how SME promotes international trade in low and lower middle-income economies. 
The definition of SMEs has never met a consensus in the literature. However, what is unique is that almost all countries have a clear definition and classification of SMEs in their economies. Examples of national definitions of SMEs could be found in China and other areas. The Chinese SMEs promotion law defines SMEs base on the follows. 1. The industry category the business operates, 2 . the assets of the business; 3. annual sales and 4. the employment level. In India, SMEs are measured by the employment level and sales.

Moreover, multilateral development institutions such as the World Bank Group and UNIDO have developed a standardized working definition that is used in administering the Enterprise Survey in all countries. The study definition is modelled around the World Bank's standard definition and classification of SMEs, only on the basis of employment level. It considers small enterprises as enterprises with an employment size of 6-20 people, and medium enterprises with an employment size of 20 - 99 people while a large company's employment level is above 100 employees.

\subsection{SMEs export performance and other variables}

Authors Leegwater and Shaw (2008) examined SMEs' size and found that it becomes a disadvantage in certain situations, and in other situation, size becomes an advantage. Many studies and policy leaders require Small- and Medium-sized firms to become more involved in export activities (Calof, 1994). Regrettably, their role that SMEs should play in the international market remains unclear for many researchers. Nevertheless, they want smaller firms to expand their customers' size and widen the domestic market through exports. Regardless of the vast number of studies on size and export behaviour and performance of SMEs everywhere on the globe, discrepancies in these studies findings and the absence of variance statistics prevent many researchers from acknowledging precisely the importance of firm size (Calof, 1994). In examining SMEs trade promotion, Calof (1994) considered three dimensions of export behaviour necessary for understanding SMEs trade promotion as summarized below:

1. The propensity to export;

2. Countries exporting to; and

3. Export attitudes exhibited by SMEs.

Author Calof (1994) found that while firm size is positively related to all dimensions of export behaviour, its importance was limited to the amount of variance explained by (Calof, 1994). Due to information asymmetry, smaller firms become more risk-averse, and as a result of this risk, author Calof, (1994) theorized that smaller firms would undertake growth within their local market at first before expanding into the foreign market (Calof, 1994). It shows that at some point in time, the opportunities for domestic growth will become limited, forcing the firm to die, be stagnated or forced to diversify their geographic market base to international markets and also incorporated into the export challenges by (Wilkinson \& Brouthers, 2006). By this reasoning, their entry into the international market, they have already grown to a more considerable firm status by capturing a significant market share within their domestic market (Calof, 1994). In summary, smaller firms will grow in the domestic market at least before exploring the international market (Leegwater \& Shaw, 2008).

An Empirical Framework for analysis was developed for the study modelling approach from the literature by (Leegwater \& Shaw, 2008). The author identified unexplored primary and secondary pathways for micro and small and also large enterprises participations and how they promote International trade through specific variables such as age of firms, experience of top managers, access to finance, and economic dynamism, linkages in value chains, corruption, trade openness, and Bank Private Credit among others (Leegwater, \& Shaw, 2008). As indicated in their research, the Primary pathways have a greater and more direct impact on growth (Leegwater, \& Shaw, 2008). It is the same with trade promotion on the International Frontlines. SME's participation in International Trade leads to the promotion of entrepreneurship, economic dynamism, job creation, consumer welfare, and the widening of options for consumers in the economy and creation of value chains through linkages with large firms (Leegwater \& Shaw, 2008). According to this research of Leegwater \& Shaw (2008) secondary pathways are considered as the indirect medium through which SMEs may contribute to the overall economic and social development and growth inclusive of the human capital development process, the financial market and the society as a whole. In trade promotion and or SMEs' participation, 
the secondary pathways are the indirect ways through which these SMEs promote trade, which is noticed through the openness of the economy and the macro business environment.

\subsection{The gravity equation and its origin}

The Gravity theory has its origin from the natural sciences when Sir Isaac Newton theorized it. Newton observed a fallen apple when he was thinking about the force of nature acting on the apple. Newton's theory of gravity first made its way in social science in 1962 when author Tinbergen applied it in economics (Anderson, 2016). Since then, the Gravity Model has taken a permanent seat in the empirical literature of international trade and economics due to its accuracy in the estimation of international trade flow between and among countries (Baier\& Bergstrand,2011). Author Anderson, (2016) argued that the Gravity Model over the years has successfully estimated trade flow between and among countries. Noticing that the model has long history accounting for its accomplishments for over forty (40) years of theoretical and practical successes in economics (Anderson, 2016).

The Gravity Equation, as it is referred to by some authors such as Bergstrand (2005), has been recognized for its empirical success and achievements in estimating consistency in such areas as tourism, exports performance, immigration, and community shipping. It is formulated in a log-linear form that specified that the flow from $i$ at the origin of the trade to $j$ the destination could best be explained by economic forces (Bergstrand, 2005). Also, authors Lewer \& Berg (2007) applied the gravity theory to immigration using a panel data econometric modeling for OECD Countries and found that the model could accurately explain it. They confirmed that the gravity model is the best estimator with a high explanatory power, which shows its usefulness in economics for the testing of hypotheses (Lewer \& Berg, 2007).

In 2012, author Novy derived a micro-founded gravity model, which was based on a translog demand analysis (Novy, 2012). It permits flexible substitution forms across products (Novy, 2012). This translog gravity equation also generates cost elasticity, and trade becomes more sensitive to costs when the exporting country provides minimal share impacts of the country's destination (Novy, 2012). The gravity equation has been successful in many fronts; Novy, (2012) concluded that the translog gravity equation has been, in many ways very consistent in predictions of trade outcomes among others. In a comprehensive 10 years review representing empirical facts by authors Kepaptsoglou, Karlaftis, \& Tsamboulas, (2010) found that the gravity equation has been used extensively in economics research for about 40 years due to its empirical robustness with high explanatory supremacy.

\subsection{Hypotheses}

The author used the literature and the objective of the study to develop the following hypotheses. The study tested these hypotheses using vigorous econometric operations.

Hypothesis 1 (Ho: 1) - Small and Medium firms do not significantly participate in International trade due to their size structure.

Hypothesis 2 (Ho:2): inflation, tax constrain, bank private credit, education, trade openness, rule of law and age of firms are not significant determinants of SMEs' trade promotion challenges in low and lowermiddle-income economies because managers will always get their way through the policy cycle.

Hypothesis 3 (Ho: 3) - The proliferation of SMEs in an economy does not significantly promote International trade than their counterparts, even after controlling for unknown sources for International trade promotion variables

Hypothesis 4 (Ho: 4) - For SMEs to further grow in the international market, government policy on the business environment, international linkages, or the openness of the economy is essential.

The variables in this study were all selected from the existing literature enterprise trading promotion.

Table 3.1: Author's expectation

\begin{tabular}{|l|l|}
\hline \multicolumn{1}{|c|}{ Variables } & \multicolumn{1}{c|}{ Expected signs } \\
\hline Small Enterprises & (Mixed ) \\
\hline Medium Enterprises & $(+)$ \\
\hline
\end{tabular}




\begin{tabular}{|l|l|}
\hline Inflation & $(-)$ \\
\hline Rule of Law & $(+)$ \\
\hline Age of Firms & $(+)$ \\
\hline Trade Openness & $(+)$ \\
\hline Bank Private Credit & $(+)$ \\
\hline Secondary School Enrolment & $(+)$ \\
\hline Tax Constrain & $(-)$ \\
\hline
\end{tabular}

Source: Author's summary from previous literature

\section{Research methodology}

The author deployed both mixed methods of research using panel data modes to examine and explain SMEs' trade promotion trends in low and lower-middle-income economies. In this section, the researcher also gives a complete description of the data and model used to investigate the phenomena.

\subsection{Data type and sources}

The study used two major types of data. Partially primary data used to compare the findings and inform the discussion. This was collected through the process of Key Informants Interviews (KII) conducted in Liberia with leaders, managers, and owners of SMEs.

The main data used for the analysis is a second type of data that comes from the World Bank enterprise Survey database and the WTO - Directory of Trade Statistics (DOT). The World Bank enterprise database is conducted annually by the World Bank Groups. The data used for this survey covers 2009 - 2018. The data covers variables such as SMEs' characteristics, financing, technology, and innovation as well as bribery incidence for 56 low and lower-middle-income economies, most of which are in Africa.

\subsection{Analytical and empirical frameworks}

The author used panel data models to examine the group effects, individual-specific as well as time effects. This is also meant to deal with any perceived heterogeneity or a unique effect that may be observed or not (Park, 2011). The fixed effect model is also considered to examine if intercepts may have variation within or across a group for the period studied (Park, 2011). The author deployed the random effect model to explore the variance of the difference within or across individual parameters (Park, 2011).

Based on our data, the author used a study period of the 2009 - 2018 dataset from the World Bank Enterprise Survey database to examine the SMEs' export model with a country pair fixed effects using the Poisson Pseudo Maximum Likelihood Model (PPML) as the best estimator. For the explanatory variables, the author included in the model was guided by the test of multi-collinearity using Variance Inflation Factors (VIF) and pairwise correlation similarly with (Baier \& Bergstrand, 2011).

These results were all estimated with robustness to partly take care of heteroskedasticity and serial correlations. It should be stated that Poisson and PPML models are non-linear estimators. They are preferred over OLS because of its capacity to address the heteroskedasticity better than the linear estimator, according to Authors (Silva \& Tenreyro, 2006). In the estimation, the logged independent variables are elasticity, while trade openness, bank private credit, secondary school enrolment, and tax constrain are measured in percentage points, respectively. The export level is in millions.

\subsection{Estimation procedures}

The study used a PPML estimation method with panel data modelling. According to Wooldridge, (2003) panel data usually give detailed information and compared to other models. Panel data is more informative and better reliable in estimations and its control for variability better with less collinearity, more degrees of freedom, and more efficiency reported in its model (Anderson, \& Yotov, 2016). Panel data models usually have unique ways of controlling heterogeneity through fixed or random effects (Wooldridge, 2003). 


\subsection{The models}

Model 1: The author estimates the effect of SMEs size on exports in low and lower-middle-income economies.

Model 2: The study estimates the determinants of SMEs International trade promotion equation in low and lower-middle-income countries

$$
\begin{aligned}
& \text { exportslevel }_{i t}=\beta_{0_{+}} \operatorname{logsmall}_{-} \text {firm }_{i t}+\text { logmedium_firm }_{i t}+\log _{-} c p i_{i t}+\text { logrule_law_prnk }_{i t} \\
& +\log \text { age_firm }_{i t}+\text { tradeop }_{i t}+\text { bank_privatcredit }_{i t}+2 \text { nd_schoolemrollmt }_{i t} \\
& + \text { tax_constrain }_{i t}======2
\end{aligned}
$$

Whereas:

exportslevel $i_{i t}=$ is the independent variable and is export levels over time in the equation.

$\beta=$ Is the constant term of the equation

logsmall_firm it $_{\text {s }}=$ stands for the size of Small enterprises $(<20$ employees $)$ over time and is one of our main variables of interest in this study.

logmedium_firm It $_{\text {I }}$ stands for the size of Medium enterprises (20-99 employees) over time and is one of our main variables of interest in this study.

$\log d_{-} c p i_{i t}=$ stands for Consumer price index $(2010=100)$ for various countries over time

logrule_law_prnk $k_{i t}=$ is the rule of law: percentile rank over time

$\log$ age_firm $_{i t}=$ is the age of the establishment (years) over time

tradeop $_{i t}=$ stands for trade $(\%$ of GDP) measuring trade openness over time

bank_privatcredit $_{i t}=$ stands for the domestic credit to the private sector by banks (\% of GDP) over time

2nd_schoolemrollmt $t_{i t}=$ stands for School enrolment, secondary $(\%$ gross $)$ over time

tax_constrain $_{i t}=$ stands for percent of firms identifying tax rates as a significant constraint over time.

3.5. Handling perceived endogeneity problems

Endogeneity is an associated biasedness that causes causality to occur when an explanatory variable may be used in determining a dependent variable in a model. This causes effects on each other in producing a causal relationship (Wooldridge, 2003). There are methods to settle on related problem like this. For example, when $\mathrm{Yu},(2010)$ was faced with this problem, he used an instrumental variable approach to solve this. Some authors also make use of the PPML estimation method with a country pair fixed effect approach to minimizing any perceived endogeneity problem through a method called "treatment effect on the treated" (Baier \& Bergstrand, 2011, p.6).

Since the focus of this paper does not include purely dealing with the case of establishing causality, the author used the approach done by other scholars (Leegwater \& Shaw, 2008). The author proves in equation 2 that the endogeneity between small enterprises and export level does not show any evidence of any reverse causality in the model. The author, henceforth, states that the explanation of causal relationship results from the model should be interrelated with some level of caution, despite the fact that there is no reverse causality found.

\subsection{Test of reverse causality - SMEs and export}

The author confirmed that the endogenous problem was addressed appropriately in the model, avoiding any perceived potential 'Reverse Causality.' It was dealing with using strict exogeneity variable for the parameters in the equation consistent with the approach of Andreson \& Yotov, (2016) by introducing a set of new variables as a new equation, logsmall_firm_lead4 ${ }_{i t}$, to capture both the present and the future effects of the SMEs.

Additionally, with the wisdom from econometric modeling, we, therefore, expect our new coefficients for the estimated logsmall_firm_lead $4_{i t}$ to be insignificant, statistically indicating that there is no reverse causality.

We, therefore, deployed a standard gravity model as equation three, as follows: 


$$
\begin{aligned}
& \text { exportslevels }_{i t} \\
& =\beta+\operatorname{logsmall}_{\text {firm }_{i t}}+\operatorname{logmedium}_{\text {firm }_{i t}}+\operatorname{logsmall}_{\text {firm }_{\text {lead }} i t}+\log d_{\text {cpi }} \text { it }_{\text {it }} \\
& +\operatorname{logrule}_{\text {law }_{\text {prnk }} \text { it }}+\operatorname{logage}_{\text {firm }_{i t}}+\text { tradeop }_{\text {it }}+\text { bank }_{\text {privatecredit }}{ }_{i t} \\
& +2 \text { nd }_{\text {schoolemrollmt }_{i t}}+\text { tax }_{\text {constrain }_{i t}}=========\text { equation } 3
\end{aligned}
$$

Table 3.1: Reverse Causality Test - Result

\begin{tabular}{ll}
\multicolumn{1}{c}{ Variables } & exportslevels \\
\hline & $0.37^{*}$ \\
Log small & 0.20 \\
& $1.10^{* *}$ \\
Log medium & 0.21 \\
& 0.01 \\
\hline logsmall_lead4 & 0.02 \\
\hline & $(0.10)$ \\
Log d_CPI & 0.32 \\
& $(0.19)$ \\
Log_Rule of Law & 0.11 \\
& $0.43^{*}$ \\
Log Age of Firm & 0.31 \\
& $0.01^{* *}$ \\
Trade openness & 0.00 \\
& 0.00 \\
Bank Private Credit & 0.01 \\
& $0.01 * *$ \\
Secondary School Enro & 0.00 \\
& 0.01 \\
Tax Constraint & 0.01 \\
& 14.02 \\
\hline R-Squared & 0.56 \\
Adj R-Squared & 0.54 \\
F(9,146) & 21.27 \\
Observation & 94 \\
Prob > F & 0.00 \\
\hline
\end{tabular}

Source: Author's calculation

This result shows that there is no reverse causality found in the model. As expected, our coefficient indicated by the new variable logsmall_firm_lead4 $4_{i t}$ is insignificant statistically. Therefore, the endogeneity for small firms and the level of export, as modelled by logsmall_lead4 do not show any evidence of reverse causality.

\subsection{Summary}

As discussed by the author, this research used mixed a method that uses both primary data and secondary data. The author furthered discussed that the study used a panel data approach with a PPML estimation method to investigate SMEs' trade promotion in the low and lower-middle-income economies based on World Bank classification of countries per income per capita.

Finally, in this section, the author conducted a test for reverse causality between SMEs and exports. It is confirmed by the study that there exists no evidence of reverse causality found in this research. 


\section{Results and discussion}

4.1. Descriptive statistics

Table 4.1: Descriptive statistics

\begin{tabular}{lcrrrr}
\hline \multicolumn{1}{c}{ Variable } & OBS & Mean & Std. Dev. & Min & Max \\
\hline Exports level & 171 & 22.43 & 1.48 & 18.93 & 26.19 \\
Small firms & 168 & 5.31 & 0.70 & 3.71 & 7.47 \\
Medium firms & 168 & 4.77 & 0.77 & 2.94 & 6.94 \\
Inflation & 165 & 4.79 & 0.25 & 4.46 & 5.84 \\
Rule of law & 171 & 3.01 & 0.86 & $(0.75)$ & 4.22 \\
Age of firms & 171 & 2.65 & 0.29 & 1.81 & 3.51 \\
Trade openness & 171 & 73.79 & 32.59 & 0.17 & 200.31 \\
Bank private credit & 166 & 28.19 & 27.38 & 2.63 & 175.26 \\
Education & 165 & 57.14 & 23.68 & 11.70 & 107.08 \\
Tax constraint & 170 & 32.18 & 15.09 & 3.40 & 69.90 \\
\hline
\end{tabular}

Table 4.2: Correlation test for multi-collinearity

\begin{tabular}{|c|c|c|c|c|c|c|c|c|c|}
\hline Exports Level & Small Firms & Medium Firms & Inflation & Rule of Law & Age of Firms & Trade Openess & Bank Private Credit & Education & Tax Constraint \\
\hline Exports Level & 100 & & & & & & & & \\
\hline $\begin{array}{l}\text { Exports Level } \\
\text { Small Firms }\end{array}$ & 0.00 & 100 & & & & & & & \\
\hline Medium Firms & 0.70 & 0.78 & 1.00 & & & & & & \\
\hline Inflation & 0.13 & 0.15 & 0.14 & 1.00 & & & & & \\
\hline Rule of Law & 0.08 & 0.07 & 0.15 & 0.06 & 1.00 & & & & \\
\hline Age of Firms & 0.22 & 0.10 & 0.31 & 0.10 & 0.03 & 1.00 & & & \\
\hline Trade 0peness & 0.00 & $(0.34)$ & $(0.23)$ & $(0.05)$ & 0.16 & $(0.07)$ & 1.00 & & \\
\hline Bank Private Credit & 0.18 & 0.11 & 0.33 & $(0.08)$ & 0.30 & 0.07 & 0.43 & & \\
\hline Education & 0.23 & $(0.05)$ & 0.23 & 0.03 & 0.11 & 0.13 & 0.21 & 1.00 & \\
\hline Tax Constraint & $(0.20)$ & $(0.23)$ & $(0.32)$ & $(0.08)$ & $(0.13)$ & 0.05 & 0.01 & $(0.15)$ & 1.00 \\
\hline
\end{tabular}

Source: Author's calculation

Table 4.3: VIF Diagnostic Test- The Variance Inflation Factor

\begin{tabular}{lll}
\hline Variable & VIF & 1/VIF \\
\hline Medium Firms & 4.25 & 0.24 \\
Small Firms & 3.44 & 0.29 \\
Bank Private Credit & 1.7 & 0.59 \\
Tax Constraint & 1.44 & 0.69 \\
Trade Openness & 1.41 & 0.71 \\
Age of Firms & 1.26 & 0.80 \\
Education & 1.17 & 0.85 \\
Rule of Law & 1.13 & 0.88 \\
Inflation & 1.06 & 0.95 \\
\hline
\end{tabular}


Source: Author's calculation

Note that the VIF measures how much the predictor inflates the variance of the estimated equation coefficients. It is used to explain the amount of multi-collinearity or correlation between predictors in the equation. The VIF is $1 /$ tolerance. It should always be greater than 1 or equal to 1 . When the VIF value exceeds ten, it is regarded as multi-collinearity, but in weaker models, values above 2.5 may be a cause for concern. The author conducted Hausman Fixed - Random-effects for model and the testparm test to appropriately guide this study.

4.2. Econometric Results

Table 4.4: Econometric model on SMEs Trade Promotion in Low and Lower middle-income Economies

\begin{tabular}{|c|c|c|c|c|}
\hline \multicolumn{5}{|c|}{$\begin{array}{l}\text { Dependent variable: exports levels in million } \\
\text { SMEs data from } 2009 \text { - } 2017 \text { (World bank enterprises survey) } \\
\text { (std. Err. Adjusted for } 53 \text { clusters in exporterID) }\end{array}$} \\
\hline \multicolumn{5}{|c|}{ Robust } \\
\hline Variables & Coef. & Std. Err & $\mathbf{Z}$ & $\mathbf{p}>\mathbf{z}$ \\
\hline Small enterprises & 0.1 & 0.14 & 0.72 & 0.47 \\
\hline Medium enterprises & $0.48 *$ & 0.18 & 2.66 & 0.01 \\
\hline Inflation & -0.11 & 0.22 & 0.47 & 0.64 \\
\hline Rule of law & $0.28 * *$ & 0.13 & 2.09 & 0.04 \\
\hline Age of firms & $0.5 * * *$ & 0.26 & 1.9 & 0.06 \\
\hline Trade openness & $0.01 * * *$ & 0 & 1.71 & 0.09 \\
\hline Bank private credit & $0.02 *$ & 0 & 4.94 & - \\
\hline Education & $0.01 * *$ & 0 & 2.05 & 0.04 \\
\hline Tax constrain & -0.00 & 0 & -1 & 0.32 \\
\hline Constant & $15.64 *$ & 1.21 & 12.94 & \\
\hline
\end{tabular}

Number of parameters: 62

Number of observations: 156

Pseudo log-likelihood: $-4.355 \mathrm{e}+10$

R-squared: 0.968

Option strict is: off

Note: (i) the parameters are presented with the significant signs. (ii) * indicates significant at 0.01 ; ** indicates significant at 0.05 ; and $* * *$ significant at 0.1 . The standard errors, $\mathrm{z}$ values, and $\mathrm{p}-$ values are all shown in the panel above for the ease understanding.

\subsection{Economic interpretations of the results}

The author tested the hypotheses and found that, on average, a percent increase in the small enterprise prevalence rate will lead to a 10 percent increase in exports in the trade of low and lower-middle-income economies, although this result is statistically insignificant. While a percent increase in Medium enterprise's prevalence rate will cause a 48 percent change in the trade activities of low and lowermiddle-income economies with a significance of 0.01 . The author hence force rejects the null hypothesis (Ho1).

Assessing hypothesis two, the author also found that on average, if inflation increases by a unit in percentage point, SMEs' export will decrease by 11 percentage points. This result is significant 
statistically. Also, on average, if governments in these economies make improvements in the Rule of Law by protecting property rights and enforce contracts by a percentage point, export could increase by 28 percent. This result is significant statistically at the 0.05 significance level or $5 \%$ significant. Further investigation shows that if the average age firms increases by a year, it will lead to export increases by a factor of 0.5 . Interestingly, our results are highly significant statistically at the 0.1 significance levels or $10 \%$ significant level. While, if the trade openness of these economies increases by a percent, it will lead to increases in export by 1 percent with a significant level of 0.01 or $10 \%$ statistically significant. Also, on average, a percent increase in the provision of Bank Private Credit in these economies could significantly lead to increases in exports by 2 percentage points. This result is highly statistically significant at the 1 percent significance level.

Finally, the author found that an increase in education measured by secondary school enrolment will lead to the promotion of SMEs export by 1 percent. This result is significant statistically at the 0.05 significance levels or 5\% significance, whereas a percent increase in taxes measuring the business environment could lead to decreases in exports. Therefore, the author rejects the null hypothesis (Ho:2). It could be reported that the rule of law, age of the firm, bank private credit, and education are major determinants of SMEs' trade promotion in low and lower-middle income economies while inflation and taxes are somewhat determinants as well.

\subsection{Further discussion}

The results indicate that small enterprises do not significantly contribute to international trade, while medium-sized enterprises contribute significantly to international trade promotion. This result is consistent with the theory of the firms, and the findings reported by other scholars such as Bilkey\& Tesar, (1977) conducted a study in Wisconsin, USA for all sizes of enterprises using employment level to classify the firms' category and found similarly mixed results. Also, Burton,(1987) from a study of enterprises of all sizes in the United Kingdom enterprises established similar consensus by finding mixed results. As the firm grows, they become active participants in international trade promotion. While author Kaynak \& Kothari,(1984) argued in a joint study of Canada and Texas using sales and employment levels to categorize firms' sizes, found positive correlations that indicated Small and Medium enterprises were involved in International trade promotion in these geographies.

Furthermore, in the recent literature, several scholars Feenstra, Li, \& Yu, (2011) found results similar to the finding of this study. They all argued about the relationship between a firms' size and its exporting behaviours in its international trade participation consistent also with (Neupert, Baughn, \& Dao, 2006). The novelty here is, almost all of them have reported that because of data challenges, the scope of their studies has been limited to either one or two countries. While, this study expands the literature in including 56 countries classified as low and lower-middle-income economies by the World Bank. Secondly, this study has established rule of law as a measure of Property rights protection, trade openness, the age of firms, education as measured by secondary school enrolment, and bank private credit (as a measure of access to finance by enterprises) are significant determinants of SMEs International trade promotion while inflation and tax constraints (as a measure of the Macro policy environment of these economies) are somewhat determinants of the SMEs international trade promotion in low and lower-middle-income economies.

\subsection{Summary of findings}

The table below gives a clear Summary of the Findings from this research as a take-home.

Table 4.5: Summary of findings and take-home message

\begin{tabular}{|l|l|l|l|l|}
\hline Variable & \multicolumn{1}{|c|}{ Methodology } & $\begin{array}{l}\text { Measurement } \\
\text { of SMEs }\end{array}$ & \multicolumn{1}{c|}{ Message } & \multicolumn{1}{c|}{$\begin{array}{c}\text { Economic } \\
\text { interpretation }\end{array}$} \\
\hline $\begin{array}{l}\text { Small } \\
\text { enterprises }\end{array}$ & $\begin{array}{l}\text { Standard gravity } \\
\text { model/ panel data } \\
\text { analysis - ppml } \\
\text { estimation }\end{array}$ & $\begin{array}{l}\text { Employment } \\
\text { level }\end{array}$ & $\begin{array}{l}\text { Smaller firms do not } \\
\text { significantly promote } \\
\text { international trade }\end{array}$ & $\begin{array}{l}\text { Positive } \\
\text { But not significant }\end{array}$ \\
\hline
\end{tabular}




\begin{tabular}{|c|c|c|c|c|}
\hline $\begin{array}{l}\text { Medium } \\
\text { enterprises }\end{array}$ & $\begin{array}{l}\text { Standard gravity } \\
\text { model/ panel data } \\
\text { analysis - ppml } \\
\text { estimation }\end{array}$ & $\begin{array}{l}\text { Employment } \\
\text { level }\end{array}$ & $\begin{array}{l}\text { Medium firms significantly } \\
\text { promote international trade }\end{array}$ & $\begin{array}{l}\text { Positive and } \\
\text { significant at } 1 \%\end{array}$ \\
\hline Rule of law & $\begin{array}{l}\text { Standard gravity } \\
\text { model/ panel data } \\
\text { analysis - ppml } \\
\text { estimation }\end{array}$ & $\begin{array}{l}\text { Employment } \\
\text { level }\end{array}$ & $\begin{array}{l}\text { Property right protection is a } \\
\text { significant determinant of } \\
\text { international trade promotion } \\
\text { in these economies }\end{array}$ & $\begin{array}{l}\text { Positive and } \\
\text { significant at 5\% }\end{array}$ \\
\hline $\begin{array}{l}\text { The age of } \\
\text { the firms }\end{array}$ & $\begin{array}{l}\text { Standard gravity } \\
\text { model/ panel data } \\
\text { analysis - ppml } \\
\text { estimation }\end{array}$ & $\begin{array}{l}\text { Employment } \\
\text { level }\end{array}$ & $\begin{array}{l}\text { The age of a firm is a major } \\
\text { determinant of its } \\
\text { involvement in international } \\
\text { trade promotion in these } \\
\text { economies }\end{array}$ & $\begin{array}{l}\text { Positive and } \\
\text { significant at } 10 \%\end{array}$ \\
\hline $\begin{array}{l}\text { Trade } \\
\text { openness }\end{array}$ & $\begin{array}{l}\text { Standard gravity } \\
\text { model/ panel data } \\
\text { analysis - ppml } \\
\text { estimation }\end{array}$ & $\begin{array}{l}\text { Employment } \\
\text { level }\end{array}$ & $\begin{array}{l}\text { The trade openness of the } \\
\text { country is a significant } \\
\text { determinant of international } \\
\text { trade promotion in these } \\
\text { economies }\end{array}$ & $\begin{array}{l}\text { Positive and } \\
\text { significant at } 10 \%\end{array}$ \\
\hline Education & $\begin{array}{l}\text { Standard gravity } \\
\text { model/ panel data } \\
\text { analysis - ppml } \\
\text { estimation }\end{array}$ & $\begin{array}{l}\text { Employment } \\
\text { level }\end{array}$ & $\begin{array}{l}\text { Education is a significant } \\
\text { determinant of international } \\
\text { trade promotion in these } \\
\text { economies }\end{array}$ & $\begin{array}{l}\text { Positive and } \\
\text { significant at 5\% }\end{array}$ \\
\hline Inflation & $\begin{array}{l}\text { Standard gravity } \\
\text { model/ panel data } \\
\text { analysis - ppml } \\
\text { estimation }\end{array}$ & $\begin{array}{l}\text { Employment } \\
\text { level }\end{array}$ & $\begin{array}{l}\text { The macroeconomic } \\
\text { instability negatively impact } \\
\text { smes international trade } \\
\text { promotion in these economies }\end{array}$ & $\begin{array}{l}\text { Negative } \\
\text { But not significant }\end{array}$ \\
\hline $\begin{array}{l}\text { Tax } \\
\text { constraints }\end{array}$ & $\begin{array}{l}\text { Standard gravity } \\
\text { model/ panel data } \\
\text { analysis - ppml } \\
\text { estimation }\end{array}$ & $\begin{array}{l}\text { Employment } \\
\text { level }\end{array}$ & $\begin{array}{l}\text { Instable tax policy negatively } \\
\text { impact smes international } \\
\text { trade promotion in these } \\
\text { economies }\end{array}$ & $\begin{array}{l}\text { Negative but not } \\
\text { significant }\end{array}$ \\
\hline
\end{tabular}

\section{Conclusion}

This study has explained the relationship that exists between SMEs and their international trade promotion methods in low and lower-middle-income economies in the World. Using panel data modelling with PPML estimation method that studies present cross-country evidence from recent reliable data on SMEs trade promotion in low and lower-middle-income economies as classified by the World Bank.

\subsection{Implications for policy and recommendations}

The results may have some essential implications for Public policymaking for the effectiveness of promoting international trade by SMEs in these economies through the following ways:

1. Size of the firm: For export performances in these economies, the size of the firms has a macro-level impact on International trade promotion.

2. Structural transformation of SMEs: In low and lower-middle-income economies, the structural transformation to grow from small to medium enterprise level stimulates exports and promotes International trade significantly. The author, therefore, recommends favourable policies to encourage the establishment of joint ventures, partnership, and shareholdings as of the new business model for SMEs development and capital accumulations.

3. Access to finance: Increasing bank private credits by Commercial Banks and development financing institutions could help to provide capital coverage for SMEs and reduce the capital constraints problem faced by Small enterprises in these economies.

4. Improvement in macro business environments: Property rights protection, contract enforcement by the State, and tax policies should favour SMEs in the economy if the countries want to increase their trade participation level. The author recommends flexible tax policies 
that provide incentives for SMEs trade development and building Stakeholders confidence in SMEs trading through a robust legal framework for the country.

5. 3. Trade liberalization versus education: The openness of the country trade wide is right; however, for SMEs development and internationalization, Trade liberalization should consider training and capacity enhancement for SMEs development and their entry into manufacturing services.

Using World Bank's latest economic classification for low and lower-middle-income economies, the author investigated SMEs' trade promotion patterns in these economies and found that Small enterprises do not significantly promote international trade, while Medium enterprises significantly promote international trade in these economies. On the other hand, the author also established the major determinants of SMEs international trade promotion as rule of law measured by property rights protection and contracts enforcement, education, bank private credits, the age of firms, and trade openness of the economy while inflation rate and tax constraints as somewhat determinants of SMEs trade promotion.

For these variables included in the models, the author was utterly guided by tests of multicollinearity. The author used the Pairwise correlation, the VIF, Hausman test, Testparm, and the test of reverse causality. The author found no evidence of reverse causality. However, the results in this study should be taken with caution in the policy domain.

The study also deployed an exports-led model of trade with country pair fixed effects using the Poisson Pseudo Maximum Likelihood Model (PPML) estimator as the best model. These results are carefully estimated with robustness to take care of heteroskedasticity and serial correlations partly. According to literature, Poisson and PPML are non-linear estimators, as such they are very goods and preferred over Ordinary Least Square Regression (OLS) because of its capability to address the heteroskedasticity better than Linear Estimators according to Silva \& Tenreyro, (2006) publication of the Log of [gravity] model. The explanatory power is also very high, with many of the coefficients on the independent variables being statistically significant.

Finally, in low and lower-middle-income countries, the goodness of fit for the model, is $96.7 \%$, indicating a perfect explanation of the model. Therefore, the author concludes that these determinants are essential for SMEs trade promotion development and evidenced-based public policy for the export industry of low and lower-middle-income countries.

\subsection{Novelty}

This study is, as far as the author is aware the first to study SMEs trade promotion mechanisms in low and lower-middle-income economies in the literature. It is also the first to study the determinants of international trade promotion for SMEs in these economies, which are all significant contributions to the literature on firm internationalization.

Lastly, the paper is closely related to real-life, which is the essence of scientific research. It provides the necessary knowledge for understanding the determinants of SMEs' trade promotion in the global market. By large, the study guides policy design in these economies.

\section{Limitation and study forward}

The limitation of this study is in the direction of the coverage of the KII used by the author to inform the discussion. The KII was only conducted in Liberia with SMEs engaged in exporting while the research data cover 2009 to 2018 from 56 low and lower-middle income economies. The author recommends that future researchers should expand the coverage of the KII.

\section{Acknowledgment}

Firstly, the author appreciates God almighty forgiving him the strength to undertake this study. The author would like to extend profound gratitude to Joe T. Carmooun, Research Assistant to the author, for helping in organizing the data used in this paper. Joe T. Carmooun has always been a helpful research assistant with a lot of energy and commitment to work within deadline. 
Finally, the author remains delightful to Dr. Tanya A. Garnett, Dr. John Gorlorwulu, and Dr. Jonathan C. Taylor for appointing him to serve as Lecturer of Development Policy Studies at the Graduate School of the state runs university, the University of Liberia. This position serves as a motivation for him to undertake this study and to contribute to the development of the private sector in low and lower-middleincome economies, of which Liberia is a member.

This paper was edited by Dr. Tanya A. Garnett. The author remains grateful to her for taking off time to proofread and edit this manuscript.

\section{References}

Anderson, J. E. (2016). The gravity model of economic interaction. Boston college and NBER, 1-8.

Anderson, J. E., \& Yotov, Y. V. (2016). Terms of trade and global efficiency effects of free trade agreements 1990-2002. Terms of Trade and Global Journal of International economic, 99, 279-298.

Baier, S. L., \& Bergstrand, J. H. (2011). On the endogeneity of international trade flows and free trade agreements. Researchgate, 1-54.

Bergstrand, J. H. (2005). The gravity equation in international trade : Some microeconomic foundations and empirical evidence. Jstor.org, 15:30:22.

Bilkey, W. J., \& Tesar, G. (1977). The export behavior of smaller-sized Wisconsin manufacturing firms. Journal of International Business Studies, 8(1), 93-98.

Burton, F. N.-e.-4. (1987). Profile analyses of non-exporters versus exporters grouped by export involvement. Journal of Management International Review, 38-49.

Calof, J.L. (1994). The relationship between firm fize and export behavior revisited. University of Ottawa: Journal of International Business Studies, second quarter, 367 - 387.

Corte, V. D. (2014). Towards a new model of SMEs' internationalization. In Handbook of Research on strategic management in small and sedium enterprises (pp. 204-242). IGI global.

Feenstra, R. C., Li, Z., \& Yu, M. (2011). Exports and credit constraints under incomplete information: Theory and evidence from China. Nber Working Paper Series, 1-50.

Kaynak, E., \& Kothari, V. (1984). Export behaviour of small and medium-sized manufacturers: some policy guidelines for international marketers. Jounal of Management International Review, 6169.

Kepaptsoglou, K., Karlaftis, M. G., \& Tsamboulas, D. (2010). The gravity model specification for modeling international trade flows and free trade agreement effects: A 10-year review of empirical studies. The open Economics Journal, 2010, 3, 1-13, 1-13.

Khana Group/Social Impact, (2018). Informal cross border trade survey. USAID/Liberia,Liberia Strategic Analysis Contract No: AID-669-C-16-00002 UN Drive Adjacent Gate 3 US Embassy, Monrovia, Liberia, POC: Dala T. Korkoyah, dkorkoyah@socialimpact.com

Leegwater, A., \& Shaw, A. (2008). The role of micro, small, and medium enterprises in economic growth: A cross-country regression analysis. The IRIS center, University research Corporation International.

Lewer, J. J., \& Berg, H. V. (2007). A gravity model of immigration. Elsevier, 164-167.

Neupert, K. E., Baughn, C. C., \& Thanh Lam Dao, T. (2006). SME exporting challenges in transitional and developed economies. Journal of Small Business and Enterprise Development, 13(4), 535-545

Novy, D. (2012). International trade without CES: Estimating translog gravity. Journal of International Economics, 271-282.

OECD. (2000). Small and Medium-sized Enterprises: Local strength, global reach. Organisation for $(0$ OECD 2000 Economic Co-operation and Development - observers, 1-9.

Park, H. M. (2011). Practical guides to panel data modeling: A step by step. Public Management and Policy AnalysisPprogram, 1-53.

Paul, J., Parthasarathy, S., \& Gupta, P. (2017). Exporting challenges of SMEs: A Review and future Research agenda. Journal of World Business, 52(3), 327-342

Silva, J. S. \& Tenreyro, S. (2006). The log of gravity. The Review of Economics and Statistics, 88(4), 641-658.

Wight, M., Wight G., \& Bull, H. (1991). International theory: The three traditions. Leicester 
University press for the Royal Institute of International Affairs. London, UK, 13-15.

Wilkinson, T., \& Brouthers, L. E. (2006). Trade promotion and SME export performance

International Business Review, 15(3), 233-252

Wooldridge, J. M. (2003). Cluster-sample methods in applied econometrics. . American Economic Review, 93(2), 133-138.

$\mathrm{Yu}$, M. (2010). Trade, democracy, and the gravity equation. Journal of Development Economics, 91(2), 289-300. 